\title{
OŠETROVATEL'SKÉ DIAGNÓZY A INTERVENCIE V KLINICKEJ PRAXI
}

\author{
Gabriela Vörösová, Andrea Solgajová, Dana Zrubcová \\ Katedra ošetrovatel'stva FSVaZ UKF Nitra \\ gvorosova@ukf.sk, asolgajova@ukf.sk,dzrubcova@ukf.sk
}

\begin{abstract}
Abstrakt: Východiská: Validácia ošetrovatel'ských diagnóz je dôležitá najmä pre zvýšenie presnosti $\mathrm{v}$ ošetrovatel'skej diagnostike, štandardizácii ošetrovatel'skej terminológie a $\mathrm{k}$ zefektívneniu uplatňovania intervencií v ošetrovatel'stve.

Ciel: Ciel'om bolo zmapovat' dokumentovanie ošetrovatel'ských diagnóz sestrami v zdravotných dokumentáciách na vybraných pracoviskách SR a ČR a zistit', ktoré ošetrovatel'ské diagnózy a ich typy, sestry stanovujú, a ktoré ošetrovatel'ské intervencie dokumentujú. Ďalej bolo ciel'om aj zmapovat' názory sestier na danú problematiku.

Metódy: Administrovali sme zberný hárok, ktorý obsahoval 11 bodov pre zmapovanie údajov v zdravotných dokumentáciách. Výberový súbor tvorilo $\mathrm{n}=120$ pacientov retrospektívne zo zdravotných dokumentácií na vybraných pracoviskách SR (JIS- chirurgická klinika, pediatrická klinika, onkologické oddelenie) a na vybraných pracoviskách ČR (Anesteziologicko-resuscitačné, Centrum následnej starostlivosti (CNS), Detské kardiocentrum, Gynekologicko-pôrodnícke oddelenie). Anketový hárok vyplnilo n= 30 sestier $\mathrm{z}$ vybraných pracovísk. Výsledné dáta sme analyzovali a komparovali prostredníctvom absolútnych a relatívnych č́siel.

Výsledky: Na vzorke $\mathrm{n}=120$ pacientov sme z dokumentácie určili 434 ošetrovatel'ských diagnóz. Na vybraných pracoviskách SR u $\mathrm{n}=60$ pacientov bolo uvedených 85 ošetrovatel'ských diagnóz a dokumentovaných 356 ošetrovatel'ských intervencií, na vybraných pracoviskách ČR u n=60 pacientov bolo uvedených 349 ošetrovatel'ských diagnóz a dokumentovaných 1142 ošetrovatel'ských intervencií. Môžeme konštatovat', že sestry sa najviac zameriavali na ošetrovatel'ské diagnózy v doméne 11. Bezpečnost' a ochrana. Menej sa venovali ošetrovatel'ským diagnózam s psychickými problémami a najmenej určovali sociálne a spirituálne diagnózy.

Implikácie: Sestry vybraných pracovísk dokumentujú vo svojej praxi ošetrovatel'ské diagnózy zaoberajúce sa potrebami bezpečia a ochrany, aktivity a odpočinku, výživy a menej sa venujú psycho-sociálnym a spirituálnym potrebám. Domnievame sa, že dôvodom je aj ich zložitost' v uspokojení pacienta v týchto narušených potrebách.
\end{abstract}

Klúčové slová: Ošetrovatel'ská diagnóza. Intervencia. Klinická prax. Dokumentovanie. Sestra.

\section{ÚVOD}

Ošetrovatel'stvo má jedinečný predmet skúmania problematiku potrieb človeka, rodiny a komunity. Najvýznamnejšou podporou pozorovania toho ako sa mení stav zdravia, je rozvoj diagnostickej terminológie. Ošetrovatel'ské diagnostikovanie môže slúžit' k vytvoreniu celého rámca pre plánovanie, ktoré vychádza z ošetrovatel'ských diagnóz. Jedným z najvýznamnejších nástrojov doloženia ošetrovatel'skej praxe je teda dokumentovaná podoba výstupov ošetrovatel'skej diagnostiky. Popredné vysvetlenia rozvoja štandardizovanej diagnostickej terminológie sú :

1) Presné určenie ošetrovatel'skej profesie, vyznačenie činností, ktoré zdravotné sestry vykonávajú a presné určenie roli sestry pri ošetrovatel'skej starostlivosti o l’udí v primárnej, sekundárnej a terciárnej starostlivosti. 
2) Zdokonalenie komunikácie pri poskytovaní ošetrovatel'skej starostlivosti, pri uskutočňovaní vyhodnocovania a pri pozorovaní úrovne kvality v ošetrovatel'stve.

3) Spracovanie ošetrovatel'skej dokumentácie do elektronickej podoby a vývoj informačných systémov v ošetrovatel'stve.

Vörösová a kol. (2015) uvádzajú, že ošetrovatel'ské diagnózy obsahujú len tie zhoršené potreby, ktoré sú sestry zručné a kvalifikované vykonávat'. Ošetrovatel'ská diagnóza je ukončenie, ktoré je uskutočnitel'né len v prípade svedomitého a usporiadaného procesu získania dát.

Lunneyová (2010, s.4-5) uvádza, že sú prítomné dva predpoklady, pre vývoj diagnostických kompetencií v ošetrovatel'stve:

1) Ošetrovatel'ská diagnóza vyžaduje kompetencie $v$ oblasti technickej, medzil'udskej a intelektuálnej.

2) Diagnóza v ošetrovatel'stve si vyžaduje vývoj osobnostnej stránky, tolerantnost' dvojitého významu a praktizovanie reflexívnej praxe.

Žiaková et al. (2013, s. 602) citujú Paans et al.(2011, s. 2389) nazvali štyri skupiny činitel'ov, ktoré pôsobia na používanie a prehl'ad ošetrovatel'ských diagnóz v klinickej praxi:

1) Diagnostické kompetencie - obsahujú názor a zasadzovanie k diagnóze, poznatky ktoré majú vzt’ah k istým problémom a diagnostike, praktické vedomosti pri odôvodňovaní a uvažovaní pri konkrétnej diagnóze.

2) Prostriedky a vzdelávanie v oblasti diagnostiky - zahŕňajú klinické dôvody, výchovu v úseku ošetrovatel'ského procesu, hodnotiace systémy a usporiadané dokumentačné záznamy

3) Zložitost', komplexnost' situácií pacienta - obsahuje pacientovo, klientovo rozdielne pomenovanie svojich problémov pre ich diferentnú kultúru, druh pomenovania významných diagnóz, významných medicínskych diagnóz v podstatných úsekoch.

4) Nemocničná politika a prostredie - predstavuje kol'ko pacientov je na jednu sestru v službe, psychický a fyzický tlak na sestru v práci, časové obdobie ktoré strávi sestra nad ošetrovatel'skými diagnózami, nadradenost' biochemického modelu, tlak zo strany písania dokumentácie a iných administračných záležitostí, pozíciu ktorú zastavajú lekári smerom k diagnostike v ošetrovatel'stve, forma akou sa realizujú, píšu dokumentácie na oddelení.

Odborníci v ošetrovatel'stve zdôrazňujú nutnost' validovat' ošetrovatel'ské diagnózy pre rozvoj presného názvoslovia, ktoré opisuje ošetrovatel'ské javy. Hlavným ciel’om validácie ošetrovatel'ských diagnóz je zvýšit' presnost' v ošetrovatel’skej diagnostike, štandardizácie ošetrovatel'skej terminológie a taktiež vylepšit' efektívnost' intervencií v ošetrovatel'stve. Čím viac je ošetrovatel'ský diagnostický záver validnejší, tým zrozumitel'nejšie vyjadruje momentálnu situáciu klienta, rodiny alebo komunity. Slovenské podmienky ošetrovatel'stva, v ktorých sa stretávame s rôznymi publikáciami sa od seba líšia rozsahovo aj terminologicky. Jedná sa najviac o české publikácie a preklady anglických originálnych textov. Do budúcnosti je nutné jednoznačne určit', ktorý preklad využívat' v klinickej praxi a zjednotit’ terminológiu, aj pre oblast' komunitnej starostlivosti (Tóthová et al., 2014). Aj ked' český jazyk je nám blízky, vyskytujú sa termíny, ktoré sú v týchto jazykoch odlišné. Z toho dôvodu je nutné zabezpečit' kodifikovaný slovenský preklad.

\section{CIEL' PRÁCE}

Zmapovat' pomocou zberného hárku zaznamenávanie ošetrovatel'ských diagnóz sestrami v zdravotných dokumentáciách na vybraných pracoviskách v Slovenskej a Českej republike. Zistit', ktoré zložky ošetrovatel'skej diagnózy sestry stanovujú a aké najčastejšie druhy ošetrovatel'ských diagnóz a ošetrovatel'ských intervencií stanovujú do zdravotných dokumentácií v Slovenskej a Českej republike. Zmapovat’ pomocou anketových hárkov názor sestier na danú problematiku. 


\section{METÓDY}

Informácie sme získali obsahovou analýzou zdravotnej dokumentácie a prostredníctvom ankety určenej sestrám, ktorá bola anonymná a dobrovol'ná. Administrovali sme zberný hárok, ktorý obsahoval 11 bodov pre zmapovanie údajov v zdravotných dokumentáciách. Skúmali sme frekvenciu používania ošetrovatel'ských diagnóz pri jednotlivých lekárskych diagnózach, či je dodržaná správna formulácia v súlade s vyhláškou MZ SR č. 306/2005 na Slovensku a v Českej republike podl'a Věstníku MZ ČR č. 9/2004. Anketový hárok pre sestry na vybraných pracoviskách obsahoval 4 otázky, mapoval vedomosti sestier o klasifikačných systémoch $\mathrm{v}$ ošetrovatel'stve a postoje $\mathrm{k}$ inováciám ohl'adne ich používania $\mathrm{v}$ klinickej praxi. Výsledky sme porovnali vo vybraných zariadeniach v Slovenskej a v Českej republike.

\section{Súbor}

Výberový súbor bol cielený $n=120$ respondentov, bol tvorený retrospektívne zo zdravotných dokumentácií na vybraných pracoviskách vo Fakultnej nemocnici Nitra (Chirurgická klinika - JIS, Pediatrická klinika, Onkologické oddelenie) a Fakultnej nemocnici Motole v Prahe (Anesteziologicko-resuscitačné (ARO), Centrum následnej starostlivosti (CNS), Detské kardiocentrum, Gynekologicko-pôrodnícke oddelenie (GYP). Anketový hárok vyplnilo n= 30 sestier z vybraných oddelení vo Fakultnej nemocnici Nitra. Výsledné dáta sme analyzovali a komparovali prostredníctvom absolútnych a relatívnych čísel.

\section{Výsledky}

Uvádzame výsledky výskumu v prehl'adných tabul'kách 1, 2, 3, 4 a grafe 1.

Tabul'ka 1 Výskumná vzorka podl'a pohlavia

\begin{tabular}{|l|l|l|}
\hline FN Nitra/oddelenie & Ženy & Muži \\
\hline Chirurgia - JIS & 5 & 7 \\
\hline Onkológia & & 22 \\
\hline Pediatria & 15 & 11 \\
\hline Spolu & $\mathbf{2 0}$ & $\mathbf{4 0}$ \\
\hline FN Motol/oddelenie & & \\
\hline ARO & 3 & 4 \\
\hline CNP & 11 & 10 \\
\hline Detské kardiocentrum & 4 & 8 \\
\hline GYP & 20 & \\
\hline Spolu & $\mathbf{3 8}$ & $\mathbf{2 2}$ \\
\hline Všetci spolu & $\mathbf{5 8}$ & $\mathbf{6 2}$ \\
\hline
\end{tabular}


Tab. 2 Komparácia ošetrovatel'ských diagnóz

\begin{tabular}{|l|c|c|c|c|c|c|c|}
\hline FN Nitra/doména & $\mathbf{2}$ & $\mathbf{3}$ & $\mathbf{4}$ & $\mathbf{5}$ & $\mathbf{9}$ & $\mathbf{1 1}$ & $\mathbf{1 2}$ \\
\hline Chirurgia - JIS & & & & 2 & 6 & 4 & 2 \\
\hline Onkológia & 5 & 4 & 2 & 1 & 1 & 14 & 11 \\
\hline Pediatria & & 9 & & & 6 & 14 & 4 \\
\hline Spolu & $\mathbf{5}$ & $\mathbf{1 3}$ & $\mathbf{2}$ & $\mathbf{3}$ & $\mathbf{1 3}$ & $\mathbf{3 2}$ & $\mathbf{1 7}$ \\
\hline FN Motol/doména & & & & & & & \\
\hline ARO & 10 & 12 & 7 & 7 & 6 & 7 & 7 \\
\hline CNP & 20 & 30 & 72 & & & 66 & 7 \\
\hline Detské kardiocentrum & 5 & 8 & 5 & 5 & 4 & 15 & \\
\hline GYP & & & & 1 & 18 & 29 & 8 \\
\hline Spolu & $\mathbf{3 5}$ & $\mathbf{5 0}$ & $\mathbf{8 4}$ & $\mathbf{1 3}$ & $\mathbf{2 8}$ & $\mathbf{1 1 7}$ & $\mathbf{2 2}$ \\
\hline Celkom spolu & $\mathbf{4 0}$ & $\mathbf{6 3}$ & $\mathbf{8 6}$ & $\mathbf{1 6}$ & $\mathbf{4 1}$ & $\mathbf{1 4 9}$ & $\mathbf{3 9}$ \\
\hline
\end{tabular}

Celkový súčet ošetrovatel’ských diagnóz z FN Nitra a FN Motol je 434. Výsledky nasvedčujú tomu, že sestry určovali najviac ošetrovatel'ských diagnóz z domény 11. (n=149). Možno konštatovat', že sestry najviac dbajú na bezpečnost' a ochranu pacienta. Menej riešia ošetrovatel'ské diagnózy z domén 5, 9, 12. Tieto domény sa zaoberajú ošetrovatel'skými diagnózami, ktoré vyjadrujú subjektívne t’ažkosti pacienta, psychociálne a spirituálne problémy. Nezaznamenali sme ošetrovatel'ské diagnózy, ktoré patria pod doménu 1. Podpora zdravia, doménu 6. Sebapercepciu, $\mathrm{z}$ domény 8 . Sexualita, diagnózy z domény 10 . Životné princípy.

Tab. 3 Komparácia druhov ošetrovatel’ských diagnóz

\begin{tabular}{|l|c|c|}
\hline FN NITRA & $\begin{array}{c}\text { Aktuálne } \\
\text { ošetrovatel'ské } \\
\text { diagnózy }\end{array}$ & $\begin{array}{c}\text { Rizikové } \\
\text { ošetrovatel'ské } \\
\text { diagnózy }\end{array}$ \\
\hline Chirurgia - JIS & 10 & 4 \\
\hline Onkológia & 19 & 19 \\
\hline Pediatria & 19 & 14 \\
\hline Spolu: & $\mathbf{4 8}$ & $\mathbf{3 7}$ \\
\hline FN Motol & 49 & 7 \\
\hline ARO & 129 & 66 \\
\hline CNP & 27 & 15 \\
\hline $\begin{array}{l}\text { Detské } \\
\text { kardiocentrum }\end{array}$ & 27 & 29 \\
\hline GYP & $\mathbf{2 3 2}$ & $\mathbf{1 1 7}$ \\
\hline Spolu & $\mathbf{2 8 0}$ & $\mathbf{1 5 4}$ \\
\hline Celkom spolu & & \\
\hline
\end{tabular}


Ako sme zistili častejšie sestry pri diagnostikovaní využívajú aktuálne diagnózy voboch zdravotníckych zariadeniach.

Tab. 4 Komparácia ošetrovatel'ských intervencií

\begin{tabular}{|l|c|c|c|c|c|c|c|}
\hline $\begin{array}{l}\text { FN } \\
\text { NITRA/doména }\end{array}$ & $\mathbf{2}$ & $\mathbf{3}$ & $\mathbf{4}$ & $\mathbf{5}$ & $\mathbf{9}$ & $\mathbf{1 1}$ & $\mathbf{1 2}$ \\
\hline Chirurgia - JIS & 17 & 7 & 47 & 24 & 25 & 34 & 7 \\
\hline Onkológia & 14 & 10 & 29 & 18 & 5 & 13 & 14 \\
\hline Pediatria & 10 & 12 & 32 & & 17 & 9 & 12 \\
\hline Spolu & $\mathbf{4 1}$ & $\mathbf{2 9}$ & $\mathbf{1 0 8}$ & $\mathbf{4 2}$ & $\mathbf{4 7}$ & $\mathbf{5 6}$ & $\mathbf{2 4}$ \\
\hline FN Motol & & & & & & & \\
\hline ARO & 33 & & 145 & 41 & 3 & 112 & \\
\hline CNP & 62 & 65 & 200 & & & 112 & 30 \\
\hline $\begin{array}{l}\text { Detské } \\
\text { kardiocentrum }\end{array}$ & 17 & 7 & 19 & 16 & 12 & 93 & \\
\hline GYP & & & & 4 & 55 & 90 & 21 \\
\hline Spolu & $\mathbf{1 1 2}$ & $\mathbf{7 2}$ & $\mathbf{3 6 4}$ & $\mathbf{6 1}$ & $\mathbf{7 0}$ & $\mathbf{4 0 7}$ & $\mathbf{5 1}$ \\
\hline Celkom spolu & $\mathbf{1 5 3}$ & $\mathbf{1 0 1}$ & $\mathbf{4 7 2}$ & $\mathbf{1 0 3}$ & $\mathbf{1 1 7}$ & $\mathbf{4 6 3}$ & $\mathbf{7 5}$ \\
\hline
\end{tabular}

$\mathrm{Na}$ Slovensku vo FN Nitra sme pri $\mathrm{n}=60$ respondentoch a pri 85 dokumentovaných ošetrovatel'ských diagnózach, zaznamenali 356 ošetrovatel'ských intervencií. Sestry najviac intervencií zamerali na doménu 4., ktorá vyjadruje aktivitu a odpočinok pacienta. Doména 11., $\mathrm{s}$ názvom bezpečie a ochrana mala 56 ošetrovatel'ských intervencií po súčte na všetkých úsekoch v FN Nitra. Ďalej sestry zamerali svoje intervencie s celkovým počtom 47 na doménu 9., ktorá sa zameriava na zvládanie a toleranciu zát’aže. Vo FN v Motole sme zaznamenali pri n=60 respondentoch a 349 ošetrovatel'ských diagnóz celkovo na všetkých úsekoch 1142 ošetrovatel'ských intervencií. Najviac ošetrovatel'ských intervencií sestry zamerali na doménu 11., ktorá vyjadruje bezpečnost' a ochranu. S počtom 364 ošetrovatel'ských intervencií mala doména 4., ktorá sa zameriava na aktivitu a odpočinok. Ďalej sa sestry zameriavali na doménu 2. výživu u pacientov s počtom ošetrovatel'ských intervencií 112. Podobne na doménu 3. a 9., ktorá vyjadruje zvládanie a toleranciu zát’aže.

Graf 1 NANDA-I systém je prínosom do klinickej praxe sestier?

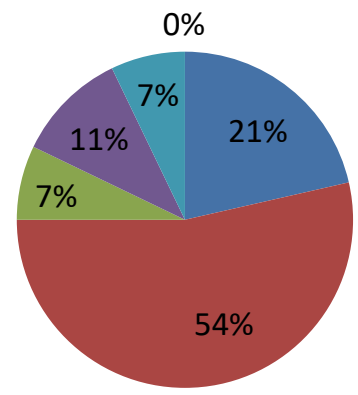

- Rozhodne áno

- Skôr áno, ako nie

- Skôr nie, ako áno

- Nie

- Čiastočne

- Neviem sa vyjadrit' 
Zo zistení môžeme konštatovat', že väčšina sestier systém NANDA-I pozná, hoci s ním nepracuje. Tento klasifikačný systém je vyučovaný na vysokých školách, čím by sa dala vysvetlit' absencia jeho poznania u 7 \% sestier, čo v podstate zodpovedá vzdelanostnej štruktúre výskumnej vzorky.

\section{DISKUSIA}

Ošetrovatel'ská diagnóza sa buduje na osobnosti a zdraví klienta, prijíma pohl'ad na človeka v holistickom smere. Treba aj upozornit', že bez lekárskej diagnózy nemôže byt' ošetrovatel'ská diagnóza, pretože je nemožné vynechat' informácie o zdravotnom stave pacienta. Teda významným dodávatel’om informácií o zdravotnom stave pacienta je lekárska diagnóza. Záverom systematického zhromažd'ovania a zakladania informácií o klientovi je ošetrovatel'ská diagnóza. Opisuje aktuálny stav pacienta alebo stav, ktorý môže nastat' u klienta. Ošetrovatel'ská diagnóza je výsledkom procesu posúdenia pacienta sestrou. Ošetrovatel'ská diagnóza je východiskom pre vol'bu a realizáciu ošetrovatel'ských intervencií na dosiahnutie stanovených ciel'ov a výsledkov, za ktoré nesie zodpovednost' sestra (Boledovičová, Vörösová, In Žiaková et. al., 2009, s. 100., Herdman, 2009, s.367).

Osobu v ošetrovatel'stve vnímame ako celok, teda pozeráme na pacienta holisticky, neustále a cielene vyhl'adávame deficity $\mathrm{v}$ jeho bio-psycho-sociálnych a duchovných potrebách. Pavelová et al. (2005) vo svojom výskume vintenzívnej ošetrovatel'skej starostlivosti zmapovali 216 ošetrovatel'ských problémov. V podmienkach nášho výskumu na vzorke $n=120$ pacientov, celkovo sme z dokumentácie určili 434 ošetrovatel'ských diagnóz. Vo FN Nitra u n=60 pacientov bolo uvedených 85 ošetrovatel'ských diagnóz, vo FN v Motole u n=60 pacientov bolo uvedených 349 ošetrovatel'ských diagnóz. Môžeme konštatovat' na základe zistených údajov, že sestry sa najviac zameriavali na ošetrovatel'ské diagnózy v doméne 11. Bezpečnost' a ochrana. Sestry riešili vo väčšej miere ošetrovatel'ské diagnózy zamerané na somatické problémy, menej sa venovali ošetrovatel'ským diagnózam s psychickými problémami a najmenej v našom výskume určovali sestry sociálne a spirituálne diagnózy. Podobným záverom prišli aj Pavelová et al. (2005).

Mynaříková, Žiaková (2014) k problematike používania ošetrovatel'skej diagnostiky v klinickej praxi uvádzajú, že medzi faktory ovplyvňujúce presnost' a výskyt ošetrovatel'ských diagnóz v praxi patrí vzdelanie sestier, skúsenosti sestier $\mathrm{v}$ ošetrovatel'skej diagnostike, organizácia ošetrovatel'skej starostlivosti, technologické zabezpečenie ošetrovatel'skej dokumentácie ale aj podpora od inštitúcie. V japonskej štúdii Ogasawara et. al. (2005) zist’ovali požívanie ošetrovatel'ských diagnóz a ošetrovatel'ských intervencií u pacientok v terminálnom štádiu ochorenia rakoviny prsníkov. Uskutočnili obsahovú analýzu 150 ošetrovatel'ských záznamov za tri mesiace. $V$ konečnom počte vyzbierali 539 diagnostických záverov, vo vzt’ahu k typu diagnózy bolo použitých 96 diagnóz, 47 \% ošetrovatel'ských diagnóz bolo vybraných z NANDA-I taxonómie. Taktiež aj v tejto štúdii bolo využitých menej ošetrovatel'ských diagnóz z oblasti psychosociálnej. Mynaříková, Žiaková (2014) sa vyjadrujú k frekvencii použitia ošetrovatel'ských diagnóz, ktorá je podl'a nich rozmanitá, pravdepodobne závisí od miesta a zdravotníckeho zariadenia. Lucena, Barros (2006) uskutočnili výskum na identifikáciu ošetrovatel’ských diagnóz, najviac sa vyskytujúce súvisiace alebo rizikové faktory. Aj tento výskum preukázal, že diagnózy zameriavajúce sa na psychosociálne problémy a spirituálne problémy neboli tak časté ako diagnózy zaoberajúce sa základnými l’udskými potrebami.

Marečková, Tománková (2007) v Českej republike zist'ovali najfrekventovanejšie ošetrovatel'ské diagnózy u klientov s poruchami vedomia. Autorky si pripravili súbor 32 ošetrovatel'ských diagnóz, najmenej $10 \%$ frekvencie bola doložená u 29 ošetrovatel'ských diagnóz výskumného súboru. Následne zistili, že u 15 ošetrovatel'ských diagnóz bola frekvencia 100 \%. Tieto autorky 
odporúčajú pre d’alšie výskumy tohto typu vytvárat' špecifické súbory respondentov podl'a ochorenia alebo podl'a časového faktoru, tak aby boli respondenti skúmaní $\mathrm{v}$ etapách kontinuálnej starostlivosti.

Thoroddsen, Ehnfors, Ehrenberg (2010) skúmali použitie štandardizovanej ošetrovatel'skej terminológie $\mathrm{v}$ ošetrovatel'ských záznamoch $\mathrm{v}$ štyroch vybraných špecializáciách a to $\mathrm{v}$ chirurgickom, internom, geriatrickom a psychiatrickom. V konečnom počte zaznamenali 1261 diagnostických záverov, vo vzt’ahu k typom diagnóz bolo využitých 63 diagnóz v rámci spomenutých štyroch špecializačných jednotiek starostlivosti. Výskum ukázal, že najčastejšie ošetrovatel'ské diagnózy vo všetkých štyroch špecializáciách predstavujú diagnózy zamerané na základné l'udské potreby pacientov.

Jarošová (2012) uvádza výskum a jeho výsledky a ošetrovatel'skej praxi v oblasti ošetrovatel'skej diagnostiky, plánovania a dokumentovania ošetrovatel'skej starostlivosti. Projekt mal štyri ciele, a jeden z týchto ciel'ov bolo vytvorenie základného súboru ošetrovatel'ských diagnóz NANDA-I a NIC pre podmienky ošetrovatel'skej klinickej praxe. Výsledky výskumu poukazujú na to, že používanie jednotnej terminológie a zvlášt' NIC, môže byt' výrazne nápomocná a užitočná pre popis a evidencie práce sestier $v$ klinickej praxi.

Z nášho výskumu zameraného na ošetrovatel'ské intervencie, konštatujeme že sestry ovela viac intervencií určujú vo FN Motol ako vo FN Nitra. Dôvodom je podl'a nás, že sestry v FN Motol majú k dispozícií plán ošetrovatel'skej starostlivosti, kde majú vopred stanovené ošetrovatel'ské intervencie k príslušným ošetrovatel'ským diagnózam.

Náš anketový prieskum sestier v klinickej praxi poukázal na fakt, že sestry by s inováciami, ktoré sa týkajú NANDA-I súhlasili n=22,5 (75 \%) z n= 30 sestier, ktoré sa zapojili do výskumu. Sestry v FN Motol používajú plány ošetrovatel'skej starostlivosti a preto zaznamenávajú ovel'a viac ošetrovatel'ských diagnóz a ošetrovatel'ských intervencií. Tieto plány ošetrovatel'skej starostlivosti by boli vel'kým prínosom pre sestry na Slovensku. Problémovou oblast'ou zostáva aj oblast' ošetrovatel'ských diagnóz podporujúcich zdravie, ktorá je často opomínanou, pričom sestry vyjadrujú potrebu venovat' sa rizikovým faktorom hlavne civilizačných ochorení (Šedová et al., 2016).

Vyhláška 306/2005 Z. z. zoznam sesterských diagnóz, neobsahuje všetky ošetrovatel'ské diagnózy z NANDA-I taxonómie II. Táto skutočnost' nedáva sestre možnost' porovnat' potreby, problémy pacienta $\mathrm{v}$ rovine definície, definujúcich charakteristík a súvisiacich faktorov ošetrovatel'ských diagnóz. Plán ošetrovatel'skej starostlivosti podl'a Věstníku MZ ČR č. 9/2004 obsahuje tieto zložky diagnóz, čo je pre sestry prínosom, zjednocuje sa komunikácia medzi sestrami a ostatnými zdravotníckymi pracovníkmi, šetrí čas sestrám, skvalitňuje ošetrovatel'skú starostlivost’. Výskum týkajúci sa postoja sestier k vyhláške 306/2005 Z. z. a ku klasifikačnému systému NANDA-I ukázal, že sestry by privítali tieto zmeny naklonené k inováciám diagnostiky.

\section{ZÁVER}

V práci sme došli k záveru, že je potrebné zlepšenie podmienok pre sestry, či už po stránke diagnostickej, technologickej, či zabezpečenia dostatočného personálu na jednotkách starostlivosti. Na Slovensku chýba sestrám aj inštitucionálna podpora pre zlepšenie diagnostikovania v klinickej praxi. Pre tento dôvod je zrejmé, že sestry sa pomenej venujú diagnostikovaniu a skôr aplikujú vo svojej praxi ošetrovatel’ské diagnózy zaoberajúce sa potrebami bezpečia a ochrany, aktivity a odpočinku, výživy a menej sa venujú psycho-sociálnym a spirituálnym potrebám. Domnievame sa, že dôvodom je aj ich zložitost' v uspokojení pacienta v týchto narušených potrebách. 


\section{LITERATÚRA}

Boledovičová, M., \& Vörösová, G. (2009). Ošetrovatel'ská diagnóza. In K. Žiaková et al., Ošetrovatel'ský slovník (s. 100-101). Martin: Osveta.

Herdman, H. T., et al. (2009). NANDA International Ošetřovatelské diagnózy Definice a klasifikace 2009-2011. Praha: Grada.

Jarošová, D. (2012). Ověřovaní souboru ošetřovatelských diagnóz a intervencí pro domáci péči. In D. Jarošová (Ed.), Využitelnost' oštřovatelských klasifikací NANDA Internacional a NIC v domáci péči (s. 86-99). Ostrava: OU v Ostravě.

Lucena, A. F, \& Barros, A. L. (2006). Nursing diagnoses in a Brazilian intensive care unit. International Journal of Nursing Knowledge, 17(3), 139-146.

Lunney, M. (2010). Hodnocení, klinické posouzení a ošetřovatelské diagnózy: jak určit přesnou diagnózu. In H. Herdman (Ed.), NANDA International Ošetřovatelské diagnózy, definice, klasifikace 2009-2011 (s. 3-15). Praha: Grada.

Marečková J, \& Tománková I. (2007). Diagnostické prvky NANDA International u bezvědomých pacientů. In R. Bužgová, D. Jarošová (Eds). Ošetřovatelská diagnostika a praxe založená na důkazech (s. 58-64). Ostrava: Ostravská univerzita.

Mynař́ḱková, E., \& Žiaková, K. (2014). The use of the nursing diagnosis in clinical practice. Central European Journal of Nursing and Midwifery, 5(3), 117-126.

Paans, W., et al. (2011). What factors influence the prevalence and accuracy of nursing diagnoses documentation in clinical practice? A systematic literature review. Journal of Clinical Nursing, 20(17-18), 2386-2403.

Pavelová, L'., et al. (2005). Sesterská diagnostika v ošetrovatel'skom procese u pacientov v kritickom stave. In Ošetrovatel'stvo 21. storočia v procese zmien: zborník (s. 343-346). Nitra: FSVaZ UKF.

Šedová, L., Tóthová, V., Olišárová, V., Bártlová, S., Chloubová, I., Michálková, H., Prokešová, R., Trešlová, M., \& Adámková, V. (2016). Opinions regarding the effectiveness of nonpharmacological measures in prevention of cardiovascular disease in the Czech Republic. Neuro Endocrinol Lett, 37(2), 32-38.

Thoroddsen A., Ehnfors M., \& Ehrenberg A. (2010). Nursing specialty knowledge as expressed by standardized nursing languages. International Journal of Nursing Terminologies and Classifications, 21(2), 69-79.

Tóthová, V., Bártlová, S., Šedová, L., Trešlová, M., Chloubová, I., \& Prošková, E. (2014). The nurse's role in preventive care in the field of community nursing. Neuro Endocrinol Lett, 30(35), 26-33.

Vörösová, G., Solgajová, A., \& Archalousová, A. (2015). Standardizovaná terminológia pro ošetřovatelskou diagnózu. Praha: Grada Publishing.

Žiaková, K., et al. (2009). Ošetrovatel'ský slovník. Martin: Osveta.

Žiaková, K., Gurková, E., Šerfelová, R., \& Čáp, J. (2013). Stimuly a bariéry vo využívaní ošetrovatel'ských diagnóz. Ošetřovatelství a porodní asistence, 4(3), 601-608.

Věstník MZ ČR, č. 9/2004. Metodická opatření. Koncepce ošetřovatelství. ZN.: 21581/04/VVO.

Vyhláška MZ SR č. 306/2005 Z.z., ktorou sa určuje zoznam sesterských diagnóz. 


\section{Nursing diagnoses and interventions in clinical practice}

Abstract: Background: Nursing diagnosis validation is important for increasing the precision of nursing diagnostics, standardization of nursing terminology and for improving using of interventions in nursing practice.

Objective: The aim of the research was to find out the level of documentation of nursing diagnoses by nurses in Slovak and Czech Republic. Second aim was to study nurses' opinions on documentation.

Methods: List of 11 areas was used for analysing medical documentation. Sample consisted documentation of 120 patients in different Slovak (clinics of surgery, pediatric clinics, oncological clinic) and Czech (Anesthesiology-Resuscitation, Post-Care Center, Children's Cardiocentre, Gynecological) departments. Documentation was evaluated by 30 nurses.

Results: In the sample of 120 patients, 434 nursing diagnoses were documented. In Slovak departments in 60 patients, 85 nursing diagnoses and 356 nursing interventions were documented. In Czech departments in 60 patients, 349 nursing diagnoses and 1142 nursing interventions were documented. Most of documented nursing diagnoses belong to the domain 11: Security and Protection. Nursing diagnoses for intervention of psychical problems and the least focused on social and spiritual diagnoses were documented.

Implications: Most nursing diagnoses documented by nurses in practice dealt with security and protection needs, resting activities, and nutrition. Nurses take less care in psychosocial and spiritual needs of patients. One of the reasons why could be the complexity of satisfying these needs.

Key words: Nursing diagnosis. Intervention. Clinical practice. Documentation. Nurse.

Grantová podpora:

Príspevok bol podporený grantovou agentúrou KEGA č. 018UKF - 4/2016 Implementácia ošetrovatel'ských intervencií do multimediálnych technológií v príprave sestier. 